\title{
Ownership identity, strategy and performance: Business group affiliates versus independent firms in India
}

\author{
Sumon Kumar Bhaumik ${ }^{1}$ - Saul Estrin ${ }^{2}$ (D) \\ Tomasz Mickiewicz ${ }^{3}$
}

Published online: 30 July 2016

(C) The Author(s) 2016. This article is published with open access at Springerlink.com

\begin{abstract}
We consider whether the impact of entrepreneurial orientation on business performance is moderated by the company affiliation with business groups. Within business groups, we explore the trade-off between inter-firm insurance that enables risk-taking, and inefficient resource allocation. Risk-taking in group affiliated firms leads to higher performance, compared to independent firms, but the impact of proactivity is attenuated. Utilizing Indian data, we show that risk-taking may undermine rather than improve business performance, but this effect is not present in business groups. Proactivity enhances performance, but less so in business groups. Firms can also enhance performance by technological knowledge acquisition, but these effects are not significantly different for various ownership categories.
\end{abstract}

Keywords Emerging economies $\cdot$ Business groups $\cdot$ Entrepreneurial orientation $\cdot$ India

It is stylized that institutional voids in emerging market economies affect, among other things, ownership and organizational structures of firms (Khanna \& Rivkin, 2001; Morck \& Yeung, 2003). In particular, greater transactions cost of contract enforcement have resulted in a high share of family firms even among the larger corporations, and in significant concentration of shares in the hands of families and/or key shareholders

Saul Estrin

s.estrin@1se.ac.uk

Sumon Kumar Bhaumik

s.k.bhaumik@sheffield.ac.uk

Tomasz Mickiewicz

t.mickiewicz@aston.ac.uk

1 University of Sheffield, Western Bank, Sheffield S10 2TN, UK

2 London School of Economics, Houghton Street, London WC2A 2AE, UK

3 Aston University, Aston Triangle, Birmingham B4 7ET, UK 
(Bhaumik \& Dimova, 2014). In addition, a large proportion of these firms belong to wider business networks and in many contexts state-ownership continues to play a significant role (Gedajlovic \& Shapiro 1998; Ghemawat \& Khanna, 1998; Peng \& Delios, 2006). To a considerable extent, emergence and persistence of these ownership forms - in particular, business groups - is on account of capital market imperfections that can generally be traced back to low levels of investor and creditor protection. The latter also implies that existing firms with internal accruals are in a better position to expand, or diversify into new business ventures (Khanna \& Palepu, 2000; Riyanto \& Toolsema, 2008).

Business groups have long been of interest to researchers because of their dominant positions in emerging market economies; for example, large and successful conglomerates are ubiquitous in East and South Asia (Carney, Gedajlovic, Huegens, van Essen, \& van Oosterhout, 2011). Extant enquiry has largely focused on two different aspects of business groups, namely, the impact of business group affiliation on firm performance and the implications of business group affiliation for corporate governance of these firms (Estrin, Poukliakova, \& Shapiro, 2008; Khanna \& Yafeh, 2007). It has been argued, for example, that business group affiliation might positively contribute to a firm's performance and market value, especially in contexts where capital and factor markets remain imperfect (Keister, 1998; Khanna, 2000), and that the benefits of business group affiliation can be higher if the group is well diversified (Palepu \& Khanna, 1999). The research on corporate governance has explored the opacity of ownership structures that can be traced back to mechanisms such as the cross-holding of shares among affiliated firms (Bebchuk, Kraakman, \& Triantis, 2000; Weidenbaum, 1996), and the use of internal capital markets and other mechanisms to tunnel financial resources from one set of business group affiliated firms to another (Bertrand, Mehta, \& Mullainathan, 2002). Thus, while business groups often exhibit weak corporate governance, their existence has been seen to be an effective response to institutional weaknesses/voids in emerging market economies, thereby generating some competitive advantage for member firms as against firms that are unaffiliated.

Over the past two decades, however, emerging market economies have experienced significant changes in their economic and institutional environments (Bruton, Ahlstrom, \& Obloj, 2007; Hoskisson, Eden, Lau, \& Wright, 2000). There was a noticeable improvement in the ease of contract enforcement and, more generally, the ease of doing business in a large number of these economies (O'Neil, 2011). For example, the 2012 Doing Business report of the World Bank concluded that:

\begin{abstract}
"more and more economies are focusing their reform efforts on strengthening legal institutions such as courts and insolvency regimes and enhancing legal protections of investors and property rights. This shift has been particularly pronounced in low- and lower-middle-income economies where $43 \%$ of all reforms recorded by Doing Business in 2010/11 focused on aspects captured by the getting credit, protecting investors, enforcing contracts and resolving insolvency indicators"
\end{abstract}

(1). There has also been a considerable deepening of financial sectors in these countries and convergence in financial development between less and more developed emerging market economies (Dekle \& Pundit, 2016; Krishnan, 2011). Thus, arguments for the existence of business groups based on the market imperfections and institutional weaknesses are slowly losing their raison d'etre. But, even though there has been some 
efficiency-driven consolidation of firms within and across business groups (Carney, Estrin, Shapiro, \& van Essen, 2015), we have not observed the dissolution of (or a significant reduction in number of) business groups.

This raises the issue of whether, and in which ways, the business group structure continues to be efficient in the current emerging market context. In this paper, we go beyond the simple impact of business groups on firm performance, to consider how affiliation affects the ways in which business strategy-specifically concerning innovation, risk-taking, and proactiveness, as summarized by the construct entrepreneurial orientation (EO) - is translated into firm performance. While the impact of business group affiliation is the focus of our inquiry, we also consider similar effects for other ownership structures than domestic business groups, namely firms affiliated with a foreign multinational, state-owned, or those remaining independent of business group structures (either domestic or foreign).

Strategic decision making within business groups may be facilitated by structures which allow scarce managerial capabilities to be used to their full potential within the group. Moreover, because information flows are greater within business groups, the uncertainty associated with investment and production decisions may be reduced (Carney, 2008; Steier, 2009). Business groups provide an institutional structure within which risks can be shared and mitigated by the flow of resources across affiliated firms via internal capital markets (Khanna \& Yafeh, 2005). This implicit insurance increases the ability of affiliated firms to bear the risks that are an integral component of business strategy. However, these risk mitigation mechanisms may also adversely affect the quality of decision making within business groups, leading managers to seek internal rents rather than to innovate (Carney, 2008; Fogel, 2006; Morck $\&$ Yeung, 2004). Moreover, innovation within business group affiliates may also be negatively affected by other factors such as group diversification (Chang, Chung, \& Mahmood, 2006). Our argument therefore centers on the trade-off between the mutual insurance that enhances the ability of member firms in business groups to take risks (by enabling affiliate survival even in the event of business failure), and the inefficiencies in resource allocation which blunt managerial incentives.

There has been little prior research about the impact of business group affiliation in emerging markets on risk-taking and proactiveness, while, unlike for developed economies (Belenzon \& Berkovitz, 2010), the evidence about the impact on innovation is mixed. On the one hand, it has been argued that group affiliated firms are likely to be more innovative than their competitors in contexts where institutions are weak (Chang et al., 2006; Choi, Lee, \& Williams, 2011), that is, where the benefits from mutual insurance or internal resource sharing are high. On the other hand, empirical evidence suggests that while business groups may initially have an advantage over these competitors with respect to technological progress and productivity growth, this advantage disappears rapidly as the institutional context improves (Bhaumik \& Zhou, 2014).

In this paper, therefore, we explore how business group affiliation and also alternative ownership structures modify the impact of the components of firm's strategic EO on its performance. In doing so, we extend the line of inquiry that examines the implications of the impact of ownership concentration and identity of owners on firm performance (Gedajlovic \& Shapiro, 1998; Thomsen \& 
Pedersen, 2000). Specifically, we make three significant contributions to the literature. First, we extend the use of the construct of EO strategy to the emerging market context where the impact of risk-taking, proactivity, and innovation can be quite different. Second we theorize about the way in which ownership identity affects the effectiveness with which these strategies are translated into firm performance. This, in turn, enables us to draw implications about the efficacy of persistence of ownership (and organizational) structures such as business groups in contexts where institutional weaknesses and voids are being reduced. Finally, we provide empirical evidence from an emerging market about the moderating effects of ownership on the relationship between firm strategies and performance across a range of categories that include business groups, state-owned, and foreign-owned enterprises.

The specific context of our empirical analysis is India, where business groups are common, but unaffiliated (independent) private firms are also present in large numbers. Since the 1950s, industrial policy in India was characterized by government control over financial and other key resources, protection against competition from imports, and the so-called licence raj that provided incumbent large firms with protection from competition (Khanna, 2011). In 1991, the Indian government ushered in an era of pro-competition reforms (Douma, George, \& Kabir, 2006) that led to the gradual dismantling of the dysfunctional regulation, together with greater autonomy for the (still mostly state-owned) banks (Bhaumik \& Dimova, 2004), and the development of a modern, competitive capital market from 1994 onwards (Khanna, 2011). As a consequence, the emphasis of business strategy has shifted from investment in institutional relatedness that offered advantages with respect to access to scarce resources (Peng, 2006; Peng, Lee, \& Wang, 2005) to greater focus on valueenhancing strategies (Kedi, Mukherjee, \& Lahiri, 2006). The Indian postliberalization context therefore is ideally suited for an examination of the optimality of business groups and their affiliated firms in a changing postreform institutional environment. At the same time, it permits a meaningful analysis involving EO components understood as managerial strategies, and a comparison of the impact of EO on performance of business group affiliates, independent private firms, and those with other ownership structures.

Our results suggest that business group affiliated firms in emerging economies manage risk better relative to their independent counterparts: while the performance of independent firms declines with greater risk-taking, while that of group affiliated firms is either unaffected by or positively influenced. Hence, business group affiliation increases the firm's ability to assume risks by weakening the detrimental impact of risk-taking on enterprise performance. At the same time, the relationship between retained earnings - our measure of proactiveness - and firm's performance is weaker for business group affiliates than for their independent peers, suggesting that the return on internal resources is lower for the former than for the latter. Thus we find evidence of a trade-off between the ability to take risk and a misallocation of resources resulting from business group affiliation. Finally, we find that firms' performance is significantly and positively affected by knowledge acquisition in India, but we cannot identify any differences in this respect between group affiliated, independent, and other types of firms. 


\section{Entrepreneurial orientation (EO) strategies in an emerging market context}

Strategic decisions within the firm relate to a wide range of activities such as planning, organizational decision-making processes, and strategic management (Hart, 1992; Rajagopalan, Rasheed, \& Datta, 1993). In this context, the strategy literature on developed economies has drawn extensively on the construct of entrepreneurial orientation, EO. In the developed economy literature, EO incorporates three pillars, namely, risk-taking, pro-activeness, and innovativeness (Covin \& Slevin, 1989). ${ }^{1}$ We propose that the latter is also relevant for firms in emerging markets, capturing these generic features of innovation, risk-taking, and pro-active investment in new activities. ${ }^{2}$ Lumpkin and Dess (1996) defined EO as a "fundamental set of strategy-making processes" (139) and stylized an entrepreneurial firm as one which "engages in product market innovation, undertakes somewhat risky ventures, and is ... 'proactive' ... beating competitors to the punch" (Miller, 1983: 77). EO has become an influential model of strategy-making (Covin \& Slevin, 1991; Miller \& Friesen, 1982) that has been directly linked to firm performance (Lumpkin \& Dess, 1996). In developed countries, the aforementioned three pillars have each been found to have a positive effect on corporate performance (Miller, 1983; Miller \& Le Breton-Miller 2011). ${ }^{3}$ However, this may not be the case in emerging economies, and moreover the EOperformance link may be quite different for firms affiliated with business groups as against unaffiliated firms or other ownership types.

In particular, while all three dimensions of EO are argued to enhance firm's performance in developed economies, in emerging economy contexts their impact may be different because of institutional voids, such as the absence of insurance markets to hedge against risk. ${ }^{4}$ Indeed, Lumpkin and Dess (1996) have suggested that " $[t]$ he dimensions of an entrepreneurial orientation ... may vary independently of each other in a given context" (ibid. 151), and that the impact of EO on performance itself is context specific. This leads us to discuss the impact of each of the dimensions of EO on firm performance in emerging economies separately.

\footnotetext{
${ }^{1}$ EO represents a dimension of corporate strategy that can apply to firms or business units (Wales, Monsen, \& McKelvie, 2011), and can depend on the structure of the firm (Covin \& Slevin, 1989) as well as on factors such as the personality of the CEO (Begley \& Boyd, 1987).

${ }^{2}$ It has been argued that entirely new concepts will be required to understand business performance and especially entrepreneurship in emerging markets (see e.g., Bruton et al., 2007). Our research strategy entails modifying the existing construct with respect to knowledge, and also proposing modified, developing economy context-specific measures for the other two components of EO, as explained below.

${ }^{3}$ Following Miller (1983), it is conventional to create a composite index of EO from these three dimensions (Miller \& LeÂ Breton-Miller 2011). However, combining these into a single indicator is only feasible conceptually if they each have similar implications for firm's performance.

${ }^{4}$ According to KPMG (2013), for example, general insurance penetration (measured as ratio of premium to GDP, in percentage terms) is 1.2 in China and .7 in India, compared with 4.5 in the USA, 3.1 in the UK, and 3.6 in Germany (Exhibit 4A: 18). Further, in India, auto insurance and health insurance account for $41 \%$ and $22 \%$, respectively, of the general insurance market, while fire and engineering risks account for $4 \%$ and $5 \%$, respectively, of the market. Similarly, in 2011, the Reserve Bank of India noted that "[a] typical characteristic of the Indian interest rate market is that unlike in the overseas inter-bank funds markets, there is very little activity in tenors beyond overnight and as such there is no credible interest rate in segments other than overnight. Absence of a liquid 3-months or 6-months funds market has been a hindrance for trading in FRAs as also in swaps based on these benchmarks." In other words, firms in emerging markets such as India find it difficult (or expensive) to hedge against relevant operational and market risks.
} 


\section{Risk-taking and proactiveness}

We start with the proposition that business group affiliation may lead to be trade-offs between the first two elements of entrepreneurial orientation, risk-taking, and proactiveness. Capital markets are severely imperfect in emerging economies, so internal accruals (self-financing) are typically the dominant source of firms' investment finance (Khanna \& Palepu, 1997). Business groups are then an efficient response to the market failure, with internal capital markets extending finance opportunities and substituting for imperfect external capital markets (Riyanto \& Toolsema, 2008). For example, investment by firms affiliated to Korean chaebols is sensitive not to their own cash flow, but to the cash flow of the business group as a whole (Shin \& Park, 1999). Membership of business groups, and de facto access to cash flow of other group members, also facilitates access to external credit in contexts where the transaction costs associated with enforcing debt covenants is high (Frieman, Johnson, \& Mitton, 2003; Ghatak \& Kali, 2001).

However, reliance on internal rather than external capital markets may also have undesirable consequences. It is usually argued that business groups seek to maximize the joint profit of all affiliates (Aoki, 1984, 1988), but they may also suppress productive activities in some member firms to protect obsolete investment in others (Morck \& Yeung, 2003). ${ }^{5}$ Indeed, profits may be redistributed from stronger to weaker firms in the group (Estrin et al., 2008), potentially reducing the efficiency with which internal resources are invested (Shin \& Stulz, 1998). Thus, while business group membership offers insurance against various types of shocks, this protection comes at a cost, especially for the stronger firms within the groups; it can have adverse implications for performance and attenuate the incentives of affiliates. In addition, risk mitigation can create moral hazard, which may also affect firm performance adversely. For example, Chacar and Vissa (2005) found that Indian firms with business group affiliation exhibit greater persistence of poor performance than those without group affiliation. We therefore posit that while business groups offer insurance to their affiliates encouraging them to take risks, this comes at the cost of inefficiency in the allocation of financial resources.

Extant research usually suggests that, in the context of institutional voids, the internal capital market of business groups may lead to improved firm performance (Gedalovic \& Shapiro 2002; Khanna \& Palepu, 2000; Khanna \& Yafeh, 2007). We use the EO conceptualization to refine the argument by distinguishing between two conflicting channels influencing the choices of managers of affiliate companies. On the one hand, by providing insurance against external risks, business group affiliation makes taking risks a more effective managerial strategy. On the other hand, internal redistribution within the business group has a negative impact on managerial incentives by breaking the link between accumulated surplus and performance. The risk-insurance element and the redistributive element cannot be represented as a simple trade-off because managers in each business group affiliate face a different set of business opportunities. For some affiliate firms, risk-taking may be critical; for others, risks

\footnotetext{
${ }^{5}$ Though except for the Japanese keiretsu system (Khanna \& Yafeh, 2007), there is little direct empirical evidence about mutual insurance.
} 
may be lower, but the capacity to follow aggressive investment strategies ahead of the rivals may be the decisive factor in performance.

Now, comparing our analysis with the traditional developed economy story, we observe that risk-taking - the first strategic dimension of EO (Miller, 1983; Miller \& Le Breton-Miller 2011) — has been identified with the willingness of managers to act in a bold and decisive manner in the face of uncertainty. This can be reflected in actions such as mergers and acquisitions, risky product launches, and entry into uncertain markets. While such strategies entail an increased probability of business failure, the existence of sophisticated capital markets allow for diversification of risk and hedging. The evidence suggests that such strategies do in fact improve company performance in developed economies. However, in emerging economies these risks are exacerbated by missing insurance markets and high transactions cost of hedging, ${ }^{6}$ which may hinder or prevent risk diversification (Khanna \& Palepu, 2000). This means that while successful risk-taking could in some circumstances still enhance performance in the manner envisaged in the EO literature, the mean effect of a risk-taking strategy in emerging markets may instead be inferior performance as a consequence of ex ante credit rationing and unfavorable ex post refinancing. It may even lead to bankruptcy, or quasi-bankruptcy outcomes such as severe loss of liquidity and debt restructuring, in the event that the risk-taking decisions result in a bad outcome.

This is also why, in the emerging market context, business groups that can use their internal capital market to provide their affiliated companies with a better mechanism to manage their risks can ameliorate the potential negative impact of risk-taking on firm performance despite the absence of suitable insurance markets. The business groups' ability to insure member firms against adverse impact of risk-taking, at least in part, is largely driven by the widespread use of diversification strategies across industries, and business and product lines (Khanna \& Rivkin, 2001). While the empirical evidence does not consistently confirm the universality of mutual support and insurance within business groups, evidence for such support is strong among Asian countries (Gopalan, Nanda, \& Seru, 2007; Khanna \& Yafeh, 2007). By contrast, independent private firms that are unaffiliated to business groups have to rely on those imperfect or absent insurance markets. These firms are likely to experience at a minimum a weaker positive relationship between risk-taking and performance and given the lack of diversification and hedging opportunities, the risk-taking-performance relationship may in fact be negative for independent firms in emerging markets. Therefore, we can hypothesize the following:

Hypothesis 1 There will be a stronger positive (or weaker negative) link between risktaking and firm performance for business group affiliates, compared with independent private companies, in emerging economies.

For developed economies, the impact of proactivity, the second EO strategic pillar, is based on the idea that firms which take investment opportunities early will perform better. Strategic advantages arise from investing resources internally to seize opportunities early in the marketplace, rather than returning profits to the owners. Firms in

\footnotetext{
${ }^{6}$ In India, for example, despite growth in the foreign exchange and interest rate derivatives market, "by global standards it is still in its nascent stage" (Gopinath, 2010: 69).
} 
emerging markets face similar strategic rivalries as their counterparts in developed economies, and are positioned to reap similar benefits from the first mover advantages. In particular, proactive use of internal resources can be an advantage on account of the fact that credit and capital market frictions firms that do not use internal resources may find it difficult rapidly to take advantage of new investment opportunities. However, membership of business groups may exercise an attenuating influence on this relationship for two reasons; both related to the role played by business groups in insuring affiliated firms against the downsides of risk-taking. First, the transfer of resources from more successful business group affiliates to less successful ones, arising as a result of the insurance function of business groups, will adversely affect the incentives of managers in affiliated firms. As we have already noted, available evidence suggests that the ability of a group-affiliated firm's managers to invest depends not on its own internal resources but those of the overall group (Shin \& Park, 1999). For the more capable managers, this disincentive therefore occurs because if they are successful, they may lose the resulting additional resources to their less successful counterparts within the group. Second, unsuccessful or ineffective managers, who are insured against poor outcomes, are less motivated to succeed because they will receive resources regardless of what happens to the performance of the firm (Morck, Wolfenzon, \& Yeung, 2005). In light of these possibilities, we posit the following:

Hypothesis 2 There will be a weaker positive link between retained earnings and firm performance for business group affiliates, compared with independent private companies, in emerging economies.

\section{Acquisition of knowledge}

Innovation is typically seen as a key driver of corporate performance in developed economies, and is the third pillar of EO (Miller, 1983). However, we follow Minniti and Lévesque (2010) in arguing that innovativeness is a dimension of entrepreneurial strategy that should be seen as context-specific; its significance for company performance will depend on the level of development of the economy under consideration. In particular, the impact of innovation on firm performance in emerging markets may be affected negatively by the limited institutional support for the generation of innovation (Cuervo-Cazzura \& Ramamurti 2014). Moreover, it is often argued that firms in emerging markets have a weaker ability to learn from new techniques and innovations as a consequence of lower levels of absorptive capacity to benefit from new techniques, methods, and products (Cohen \& Levinthal, 1990; Estrin, Meyer, \& Pelletier, 2016; Li \& Atuahene-Gima, 2001).

Thus, while innovativeness is a critical dimension of entrepreneurship in mature market economies, it may be less so for firms that can make significant efficiency gains while still not operating on the technological frontier (Acemoglu, Aghion, \& Zilibotti, 2006). In the latter case, useful knowledge acquisition for firms may take a variety of forms, new knowledge creation being only one of them. Companies in the emerging economies may successfully invest in their own research and development programs, but may also gain from securing existing external knowledge via different channels. Accordingly, entrepreneurial identification of opportunities may come not from 
globally new, created, knowledge (innovation in the narrow sense of the term), but from bricolage: combining already existing knowledge in a selective way, to match local needs and conditions best. This acquired knowledge may for example take a form of licences; using information that has been already standardized and applied in mature market economies. Here, the gain in performance comes from managerial drive and the ability to identify, select, import, and apply these elements of knowledge that fit local conditions. ${ }^{7}$ To summarize, we therefore propose that within emerging economy context, the focus should be on a wider process of knowledge acquisitions rather than only on innovations. Indeed, this is recognized in studies on innovation and related issues in emerging market contexts (Bhaumik \& Zhou, 2014).

Further, the translation of acquired new knowledge into (enhanced) firm performance may be adversely affected by "the ability of a firm to recognize the value of new, external information, assimilate it, and apply it to commercial ends" (Cohen \& Levinthal, 1990: 128). In addition, the absorptive capacity of a firm may be influenced by its governance structure (Filatotchev et al., 2003). In the context of emerging economies, a key distinction is between the governance structure of independent and group affiliated firms. Hierarchical organizational structures typical for business groups may lead managers to display lower strategic flexibility and affect their capacity to absorb new knowledge ${ }^{8}$ and to respond with rapid adaptation. This problem will be exacerbated in the turbulent environments that typify emerging economies (Filatotchev, Isachenkova, \& Mickiewicz, 2007).

Moreover, as business groups accumulate knowledge, they will seek to share this internally across their affiliates. This produces efficiency gains: group affiliated firms benefit from sharing tangible and intangible resources that can include technology and knowledge generated internally, or obtained from external sources (Chang \& Hong, 2000). However, it also implies that investment in acquiring knowledge by managers of affiliate companies produce effects that are (partly) shared within the business group (i.e., the option value of knowledge acquisition is reduced because eventual payoffs are not proprietary). A combination of these two aspects implies that managers of the affiliates can to some extent free ride on a common pool of knowledge resources and has less motivation to make their own investment in acquisition. Correspondingly, consistent with Baumol (2010), we argue that there are limits to significant value enhancement from innovations within subsidiaries of large companies as compared with independent companies. Therefore, we hypothesize the following:

Hypothesis 3 There will be a weaker positive link between managerial strategies to innovate, in the broad sense of accumulating knowledge, and firm performance for business group affiliates, compared with independent private companies, in emerging economies.

\footnotetext{
7 Thus, considering the entrepreneurial use of knowledge in emerging markets brings us closer to Kirzner's stress on entrepreneurial "alertness to hitherto unnoticed opportunities" (Kirzner 1973: 39). This perspective highlights entrepreneurial uses of already existing resources, including the knowledge resources generated by others. Entrepreneurial firms in Eastern emerging markets are not necessarily radical innovators; they are firms that are able to apply existing resources in a more effective way in a given local context.

${ }^{8}$ Absorptive capacity relates to the ability of managers "to recognize the value of new information, assimilate it, and apply it to commercial ends" (Cohen \& Levinthal, 1990: 128).
} 


\section{Empirical counterpart: Variables and methods}

\section{Data}

Our sample consists of 5,152 Indian firms across 70 industrial sectors (3-digit classification). The data are an unbalanced panel over the period 2001-2011 with 32,844 firm-year observations. Our sample includes firms with four different types of ownership. Private independent firms, which we use as the omitted or benchmark category in our empirical analysis, are privately owned firms that are not part of business groups. In addition, we have business group affiliated firms, state-owned firms, and foreign owned firms.

Financial information about these companies, as well as information about ownership and industry affiliation, was obtained from the Prowess database provided by the Centre for Monitoring of the Indian Economy. Prowess is widely used for firm-level research on India; for example, Bertrand, Mehta, and Mullainathan (2002) and Gopalan, Nanda, and Seru (2007). The database includes information on both private and listed companies.

As such, 2001 is a good starting point for the sample period as much of the reform associated with institutional development and, more importantly, credit and capital markets took place in India between 1994 and 2001 (Bhaumik \& Dimova, 2004; Bhaumik, Gangopadhyay, \& Krishnan, 2009), even though some reforms can be traced back to the 1980s (Rodrik \& Subramanian, 2004). Hence, the period fits the nature of the broader research question about the efficacy of business groups in a reformed economic environment. Further, the period is long enough to include a cycle of high growth, followed by a slowdown and then recovery. Hence our estimates do not rely on a particular part of a business cycle.

\section{Dependent variable}

Our dependent variable to measure firm performance is profitability and we follow the literature (e.g., Miller \& Le Breton-Miller, 2011) in the use of return on assets (ROA). Since profit after tax (PAT) is influenced by factors such as depreciation that are affected by accounting rules, and exogenous interest payments (see, e.g., Meeks, 1977), we follow convention and use profit before interest payments and taxes (PBIT) (e.g., Bhaumik \& Selarka, 2012; Cuervo-Cazzura \& Dau, 2009); accordingly, our measure of ROA is the ratio of PBIT to total assets.

\section{Independent variables}

\section{Entrepreneurial orientation dimensions}

Consider first risk-taking, which reflects a firm's propensity to make bold moves and to embrace uncertainty. If capital markets are relatively efficient, as in developed economies, then the idiosyncratic risk associated with these actions would be reflected in a firm's share price, such that the volatility of the share price can be used as the measure of risk-taking (Fama, 1968). However, 
in emerging economies, capital market imperfections mean that observed share price volatility may be caused by factors other than managerial risk-taking, for example, strikes and work stoppages, the loss of key managerial personnel, and even localized natural disasters. The literature suggests that capital markets in India are not yet efficient (Sarkar \& Mukhopadhyay, 2005), and hence the assumptions underlying the share price methodology for measuring risk are not met. Therefore, we instead focus on internal firm's indicators and we propose that in an emerging market, a firm's cash flow volatility over a period of time will reflect the risk that it undertakes strategically (Miller \& Bromiley, 1990). Accordingly, we use the average volatility of cash flows for period $t-5$ to $t-$ 1 (i.e., the moving average) as the measure of risk taking for each period $t$ (see Stein, Usher, LaGattuta, \& Youngen, 2001). This accounting data based approach to measuring risk is also consistent with the relevant discussion in Miller and Le Breton-Miller (2011).

Next, a company is proactive if it actively engages in building the business and this is reflected in the use of its profits. Miller and Le Breton-Miller (2011) argued that proactiveness in developed economies can be measured by the percentage of profits reinvested in the company over a lengthy period of time. This is a better measure than current investment which is also affected by tactical responses to the current economic environment (Kaplan \& Zingales, 1997). The same logic holds for emerging markets, and is indeed perhaps strengthened by the relative paucity of alternative sources of finance. The use of a longer term measure is further motivated in emerging markets because in the short term cash flows may be affected by bottlenecks (Khanna \& Palepu, 1997). We therefore measure the second pillar of EO, proactiveness, by the percentage of earnings retained by the firm (and hence available for reinvestment), taken as a moving average of the past 5 years.

Turning to the third pillar, innovativeness, spending on research and development $(\mathrm{R} \& \mathrm{D})$ is usually taken as the appropriate measure in developed market economies (e.g., Miller \& Le Breton-Miller 2011). As noted above, however, in an emerging market, the focus in terms of impact on firm performance should be on the wider process of knowledge-acquisition. ${ }^{9}$ The latter might involve both the development of new products and process, and the adoption of technology, products, and processes developed by other firms. Our measure of knowledge acquisition is therefore the sum of expenditures on internal R\&D and those on externally sourced technologies (including licensing fees and royalty payments), divided by sales. As with the other two dimensions of EO, we use this as the moving average over the previous 5 years. However, given a large number of firms that had no investment in knowledge, this results in a highly skewed distribution. We therefore transform the variable further into a dummy variable for which positive levels of investment in knowledge are denoted by unity.

\footnotetext{
${ }^{9}$ Alternatively, we could use "information acquisition" if the emphasis was placed on tangible aspects (Mudambi \& Navarra, 2004). "Knowledge" implies both tangible and intangible facets.
} 


\section{Ownership}

The Prowess database distinguishes between: (1) independent private domesticowned firms that are unaffiliated with business groups, (2) firms affiliated with domestic business group, (3) state-owned firms, (4) independent foreign firms, and (5) group affiliated foreign firms (e.g., Samsung). The distribution of these ownership groups is reported in Table 1. Business group-affiliated Indian companies $(33 \%)$ and independent (unaffiliated) Indian companies (58\%) are the largest categories. We also retain in our sample independent foreign firms (5\%), group affiliated foreign firms, (1\%) and state-owned firms (3\%) but exclude the other minor ownership categories. ${ }^{10}$ Our sample accounts for $99.85 \%$ of the 31,348 firm-years for which data are available. ${ }^{11}$

Our hypotheses concern how membership of business groups, moderates the impact of the different components of EO on firm performance. However, we are also interested in the moderating effects of other ownership arrangements. To test all this, we interact each of the three dimensions of EO with the ownership categories noted above. The omitted category in our analysis is independent domestic (Indian) firms. Hence, the interactions are between the EO components and the dummy variables that account for group affiliated Indian firms, independent foreign firms, group affiliated foreign firms, and state-owned firms. We shall discuss the implications of this for the regression estimates later in the paper.

\section{Control variables}

We control for firm age and firm size, the proxy for the latter being (tangible) assets. In addition, to address the issues introduced by our measure of proactivity, we introduce a dummy variable corresponding to positive profits over the last 5 years. ${ }^{12} \mathrm{We}$ also control for the debt to equity ratio, which is an important determinant of agency costs (Jensen, 1986), and for direct ownership effects on performance. Further, we include year dummies to control for unobserved year-specific heterogeneity (11 dummies; 2001 is the omitted year) and 70 three-digit sector dummy variables. Using the likelihood ratio tests, we verified that these are needed (both significant at .001 levels).

The definitions of variables are presented in Table 1, and in Table 2 we report descriptive statistics and the correlations among the variables. Ignoring the obvious correlations, for example among the dummies that capture ownership categories, the correlation coefficients among the explanatory variables are typically below 1 .

\footnotetext{
${ }^{10}$ These are mixed state-private, cooperative, owned by non-residents, each of which account for too few firm-years - between 9 and 20-for meaningful comparison with the included ownership categories.

${ }^{11}$ Robustness checks show that the results that are related to the hypotheses are unaffected by the inclusion of the firms of the three excluded ownership categories in the sample.

${ }^{12}$ It might seem more natural to use a measure like retained earnings over total earnings to measure proactivity. However, a large number of companies have either zero or negative total earnings. Moreover, dropping those with negative earnings creates a selection bias problem. Therefore, we use a measure of retained earning normalized by total assets, and introduce this control for firms that have earnt positive profits.
} 
Table 1 Variables and measures

\begin{tabular}{|c|c|c|c|c|}
\hline Variable & Measure & Value & Mean & St. Dev. \\
\hline Profitability & $\begin{array}{l}\text { Profits before interests } \\
\text { and taxes over total } \\
\text { assets }\end{array}$ & Continuous & 4.99 & 17.38 \\
\hline $\begin{array}{l}\text { Independent } \\
\text { Indian }\end{array}$ & $\begin{array}{l}\text { Private Indian-owned } \\
\text { companies, unaffiliated } \\
\text { with business groups }\end{array}$ & 1 or 0 & .57 & .49 \\
\hline $\begin{array}{l}\text { Independent } \\
\text { foreign }\end{array}$ & $\begin{array}{l}\text { Private foreign-owned } \\
\text { companies, unaffiliated }\end{array}$ & 1 or 0 & .05 & .22 \\
\hline $\begin{array}{l}\text { Group affiliate } \\
\text { Indian }\end{array}$ & $\begin{array}{l}\text { Private Indian group- } \\
\text { affiliated companies }\end{array}$ & 1 or 0 & .33 & .47 \\
\hline $\begin{array}{l}\text { Group affiliate } \\
\text { foreign }\end{array}$ & $\begin{array}{l}\text { Private foreign-owned } \\
\text { companies, affiliated }\end{array}$ & 1 or 0 & .01 & .10 \\
\hline State-owned & $\begin{array}{l}\text { Indian state owned } \\
\text { companies }\end{array}$ & 1 or 0 & .03 & .17 \\
\hline $\begin{array}{l}\text { Retained } \\
\text { earnings }\end{array}$ & $\begin{array}{l}\text { Retained earnings over } \\
\text { total assets, 5-years } \\
\text { moving average, lagged } \\
1 \text { year }\end{array}$ & Continuous & .09 & 19.66 \\
\hline $\begin{array}{l}\text { Cash } \\
\text { variability }\end{array}$ & $\begin{array}{l}\text { Standard deviation in cash } \\
\text { flow over assets of last } \\
5 \text { years, lagged } 1 \text { year }\end{array}$ & Continuous & 9.93 & 22.48 \\
\hline $\begin{array}{l}\text { Knowledge } \\
\text { acquisition }\end{array}$ & $\begin{array}{l}\text { Expenditure on research and } \\
\text { development, royalty, licence } \\
\text { and technical know-how and } \\
\text { services fees, over total sales, } \\
\text { divided by the sector mean } \\
\text { (3-digit) of the same measure, } \\
\text { 5-years average, lagged } 1 \text { year, } \\
\text { higher than zero. }\end{array}$ & 1 or 0 & .39 & .49 \\
\hline $\begin{array}{c}\text { Tangible } \\
\text { assets }\end{array}$ & $\begin{array}{l}\text { Plant, machinery, computers and } \\
\text { electrical installations } \\
\text { (in Rs. Million) }\end{array}$ & Continuous & 2108.43 & $19,779.13$ \\
\hline Age & $\begin{array}{l}\text { Age of the firm since year of } \\
\text { establishment, mean-centred } \\
\text { (at } 28 \text { years) }\end{array}$ & Continuous & 0 & 19.83 \\
\hline Debt to equity & Debt to equity ratio & Continuous & $3.38 \times 10^{12}$ & $6.13 \times 10^{14}$ \\
\hline Positive profits & $\begin{array}{l}\text { Positive profits over the last } \\
5 \text { years }\end{array}$ & 1 or 0 & .66 & .47 \\
\hline Industry & $\begin{array}{l}\text { Indicator of the industry of the } \\
\text { firm at the 3-digit sectoral } \\
\text { level ( } 70 \text { industries) }\end{array}$ & 1 or 0 & & \\
\hline Year & $\begin{array}{l}\text { Indicator of the year (10 years: } \\
\text { 2002-2011) }\end{array}$ & 1 or 0 & & \\
\hline
\end{tabular}

\section{Model}

Our empirical model involves regressing firm profitability on risk-taking, proactiveness, and acquisition of knowledge, their interactions with business groups 


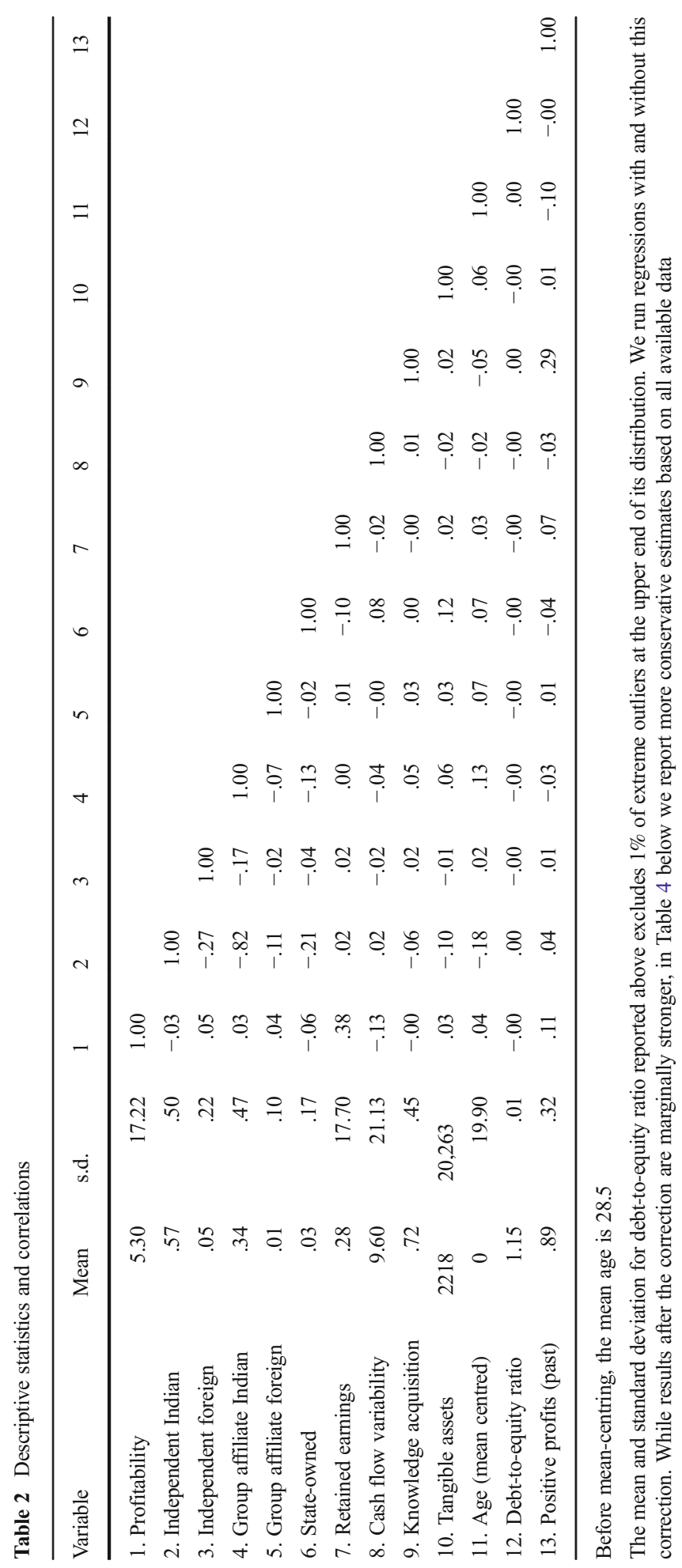


affiliation (and other ownership categories), and a number of control variables. The latter include both time varying firm characteristics (firm age, firm size, and leverage) and year- and industry-fixed effects. A dummy variable denoting positive profits was added to alleviate the potential bias in proactiveness measure related to the fact that capacity to retain profits is conditional on profitability. Hence, the regression specification we use to test our hypotheses is given by:

$$
\begin{aligned}
& \text { Profitability }_{i, t}=\beta_{0}+\beta_{1} \times \text { retained earnings }_{i, t}+\beta_{2} \times \text { cash }_{\text {volatility }}, t
\end{aligned}
$$

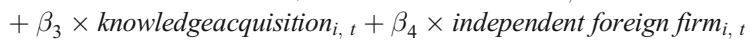

$$
\begin{aligned}
& +\beta_{5} \times \text { affiliate domestic firm } \text { fir }_{i}+\beta_{6} \times \text { affiliate foreign firm }{ }_{i, t} \\
& +\beta_{7} \times \text { state owned firm } \text { fi,t }_{i}+\beta_{8} \times \text { retained earnings }_{i, t} \times \text { independentforeign firm }_{i, t} \\
& +\beta_{9} \times \text { retained earnings } s_{i, t} \times \text { affiliate domestic firm }{ }_{i, t} \\
& +\beta_{10} \times \text { retainedearnings } s_{i, t} \times \text { affiliate foreign firm } m_{i, t} \\
& +\beta_{11} \times \text { retained earnings } s_{i, t} \times \text { state owned firm }_{i, t} \\
& +\beta_{12} \times \text { cash volatility }_{i, t} \times \text { independent foreign firm }_{i, t} \\
& \times \beta_{13} \times \text { cash } \text { volatility }_{i, t} \times \text { affiliate domesticfirm }_{i, t} \\
& +\beta_{14} \times \text { cash volatility }_{i, t} \times \text { affiliate foreign } \text { firm }_{i, t} \\
& +\beta_{15} \times \text { cash } \text { volatility }_{i, t} \times \text { stateowned firm }_{i, t}
\end{aligned}
$$

\begin{tabular}{|c|c|c|}
\hline EO component & Hypotheses & Empirical test \\
\hline $\begin{array}{l}\text { Risk (cash flow } \\
\text { variability) }\end{array}$ & $\begin{array}{l}\text { There will be a stronger positive link } \\
\text { between risk taking and profitability } \\
\text { for business group affiliates, compared } \\
\text { with independent private companies, } \\
\text { in emerging economies. }\end{array}$ & $\mathrm{H} 1: \beta_{13}>0$ \\
\hline $\begin{array}{l}\text { Pro-activeness } \\
\quad \text { (retained earnings) }\end{array}$ & $\begin{array}{l}\text { There will be a weaker positive link } \\
\text { between retained earnings and profitability } \\
\text { for business group affiliates, compared } \\
\text { with independent private companies, in } \\
\text { emerging economies. }\end{array}$ & $\mathrm{H} 2: \beta_{9}<0$ \\
\hline $\begin{array}{l}\text { Acquisition of } \\
\text { knowledge }\end{array}$ & $\begin{array}{l}\text { There will be a weaker positive link between } \\
\text { managerial strategies to innovate, in the } \\
\text { broad sense of accumulating knowledge, } \\
\text { and profitability for business group } \\
\text { affiliates, compared with independent } \\
\text { private companies, in emerging economies. }\end{array}$ & H3: $\beta_{17}<0$ \\
\hline
\end{tabular}

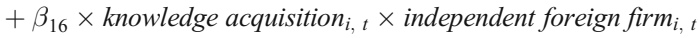

$$
\begin{aligned}
& +\beta_{17} \times \text { knowledge acquisition }_{i, t} \times \text { affiliate domestic } \text { firm }_{i, t} \\
& +\beta_{18} \times \text { knowledge acquisition }_{i, t} \times \text { affiliate foreign } \text { firm }_{i, t} \\
& +\beta_{19} \times \text { knowledge acquisition }_{i, t} \times \text { state owned firm }_{i, t} \\
& +\beta_{20} \times \text { asset size }_{i, t}+\beta_{21} \times \text { debt-equity ratio }_{i, t} \\
& +\beta_{21} \times \text { positive profits } s_{i, t} \\
& + \text { year }_{t} \boldsymbol{\Gamma}+\text { sector }_{j} \Delta+\text { firm }_{i} Z+\varepsilon_{i, t}
\end{aligned}
$$

where $i, j$, and $t$ identify firms, industries, and years, respectively. $\boldsymbol{\Gamma}$ denotes vector of coefficients on annual dummies, $\boldsymbol{\Delta}$ corresponds to coefficients on sectoral dummies, $\boldsymbol{Z}$ stands for firm-level random effects, and finally $\varepsilon$ represents the independent and

Table 3 Summary of hypotheses to be tested 
identically distributed error term. We summarize our predictions in terms of the estimation model in Table 3. Note that the omitted ownership category in our regression model is independent private firms. Hence, the estimated coefficient of an EO component in the model effectively captures the EO-performance relationship for independent private firms, while the interaction terms involving ownership categories and EO components give us the moderating impact of business group affiliation and the other ownership types on the EO-performance relationship.

We estimate the regression model in Eq. (1) using random effects estimators. In unreported regressions (available from the authors on request), we also estimate corresponding fixed effects models, the disadvantage of which is that the time invariant ownership dummies (and industry affiliation of the firms) are now absorbed into the fixed effects. The random effects models are estimated using the maximum likelihood estimator and the fixed effects model applies the within regression estimator.

\section{Results}

Table 4 reports the coefficient estimates of the random effects model in Columns 1, 2, and 3. In our baseline specification, Column 1, we estimate a truncated model including the EO components and control variables without any ownership terms. The ownership dummies and interactions between EO components and Indian business group affiliation are introduced in Column 2, and interactions with other ownership categories are added in Column 3.

The Breusch and Pagan Lagrange multiplier test for random effects suggests that random and fixed effects estimators are more suitable for estimating the model than the ordinary least square estimator (e.g., based on specification (2) we obtain LR test statistic $=4,546$, highly significant with a $p$-value of .001). Also, the likelihood-ratio test of a null hypothesis that the between-firms standard deviation of the random effect is zero is highly significant suggesting the validity of our choice of estimator. While we prefer the random effects estimator as it allows us to estimate interactions and direct ownership effects, reassuringly the regression estimates are robust across random and (unreported) fixed effects estimations with respect to all our hypotheses. For the three coefficients upon which our hypothesis testing is based (see Table 3), the fixed effects models display the same pattern of both sign and statistical significance as random effects models. ${ }^{13}$

Based both on the estimates in Columns 2 and 3 in Table 4, we find support for Hypotheses 1 and 2, but not for Hypothesis 3. Thus the coefficient on the interactive term between business groups and risk-taking is positive and significant (H1), and between business groups and proactivity is negative and significant (H2). However, the coefficient on the interaction between business groups and innovation is not statistically significant (H3). We discuss the implications of our regression estimates for the hypotheses in greater detail in the next section.

We plot Figs. 1 and 2 (based on the estimates of Column 3) to further analyze the differences between the EO-performance relationship between business group affiliates

\footnotetext{
${ }^{13}$ The magnitude of effects is sometimes attenuated in the fixed effects models (results available on request). We report differences in the text.
} 
Table 4 Estimates of profits before taxes over assets

\begin{tabular}{|c|c|c|c|}
\hline & 1 & 2 & 3 \\
\hline \multirow[t]{2}{*}{ Proactiveness (retained earnings/profits) } & $.18 * * *$ & $.20 * * *$ & $.17 * * *$ \\
\hline & $(.01)$ & $(.01)$ & $(.01)$ \\
\hline \multirow[t]{2}{*}{ Risk-taking (cash flow variability) } & $-.06^{* * *}$ & $-.07 * * *$ & $-.03 * * *$ \\
\hline & $(.00)$ & $(.00)$ & $(.01)$ \\
\hline \multirow[t]{2}{*}{ Knowledge acquisition/sales $>0$} & $1.13^{* * *}$ & $.97 * *$ & $.79 *$ \\
\hline & $(.24)$ & $(.30)$ & $(.33)$ \\
\hline \multirow[t]{2}{*}{ Tangible assets } & -.00 & -.00 & -.00 \\
\hline & $(.00)$ & $(.00)$ & $(.00)$ \\
\hline \multirow[t]{2}{*}{ Age of firm } & $.02 *$ & $.02 * *$ & $.02 *$ \\
\hline & $(.01)$ & $(.01)$ & $(.01)$ \\
\hline \multirow[t]{2}{*}{ Private foreign } & $3.31 * * *$ & $2.34 * *$ & $3.80 * * *$ \\
\hline & $(.80)$ & $(.82)$ & $(1.14)$ \\
\hline \multirow[t]{2}{*}{ Group Indian } & $.96^{*}$ & -.09 & .26 \\
\hline & $(.38)$ & $(.45)$ & $(.45)$ \\
\hline \multirow[t]{2}{*}{ Group foreign } & $3.09^{\dagger}$ & $3.17^{\dagger}$ & 2.43 \\
\hline & $(1.69)$ & $(1.69)$ & $(2.34)$ \\
\hline \multirow[t]{2}{*}{ Government } & $-5.23 * * *$ & $-5.19 * * *$ & $-3.67 * *$ \\
\hline & $(.98)$ & $(1.00)$ & $(1.24)$ \\
\hline \multirow[t]{2}{*}{ Private foreign $\times$ Proactiveness } & & & $.36^{* * *}$ \\
\hline & & & $(.03)$ \\
\hline \multirow[t]{2}{*}{ Group Indian $\times$ Proactiveness } & & $-.09 * * *$ & $-.06^{* * * *}$ \\
\hline & & $(.01)$ & $(.01)$ \\
\hline \multirow[t]{2}{*}{ Group foreign $\times$ Proactiveness } & & & $.43^{* * *}$ \\
\hline & & & $(.07)$ \\
\hline \multirow[t]{2}{*}{ Government $\times$ Proactiveness } & & & .00 \\
\hline & & & $(.01)$ \\
\hline \multirow[t]{2}{*}{ Private foreign $\times$ Risk-taking } & & & $-.33 * * *$ \\
\hline & & & $(.06)$ \\
\hline \multirow[t]{2}{*}{ Group Indian $\times$ Risk-taking } & & $.07 * * *$ & $.03^{\dagger}$ \\
\hline & & $(.01)$ & $(.02)$ \\
\hline \multirow[t]{2}{*}{ Group foreign $\times$ Risk-taking } & & & .07 \\
\hline & & & $(.09)$ \\
\hline \multirow[t]{2}{*}{ Government $\times$ Risk-taking } & & & $-.09 * * *$ \\
\hline & & & $(.01)$ \\
\hline \multirow[t]{2}{*}{ Private foreign $\times$ Knowledge } & & & $1.84^{\dagger}$ \\
\hline & & & $(1.05)$ \\
\hline \multirow[t]{2}{*}{ Group Indian $\times$ Knowledge } & & .19 & .41 \\
\hline & & $(.49)$ & $(.51)$ \\
\hline \multirow[t]{2}{*}{ Group foreign $\times$ Knowledge } & & & .79 \\
\hline & & & $(2.20)$ \\
\hline Government $\times$ Knowledge & & & .43 \\
\hline
\end{tabular}


Table 4 (continued)

\begin{tabular}{lccc}
\hline & & & $(1.31)$ \\
Debt-to-equity & .00 & .00 & .00 \\
& $(.00)$ & $(.00)$ & $(.00)$ \\
Positive profits, past (dummy) & $4.55^{* * *}$ & $4.53^{* * *}$ & $4.59^{* * *}$ \\
& $(.23)$ & $(.23)$ & $(.23)$ \\
Constant & -.00 & -2.02 & $-2.49^{\dagger}$ \\
& $(.36)$ & $(1.40)$ & $(1.37)$ \\
sigma_u & $10.57^{* * *}$ & $10.36^{* * *}$ & $10.06^{* * *}$ \\
& $(.15)$ & $(.15)$ & $(.15)$ \\
sigma_e & $12.59^{* * *}$ & $12.58^{* * *}$ & $12.56^{* * *}$ \\
& $(.05)$ & $(.05)$ & $(.05)$ \\
\hline
\end{tabular}

Observations: 32,844 in Model 1; 32,833 in Models 2 and 3

Number of companies: 5,152 in Model 1, 5,150 in Models 2 and 3

Standard errors in parentheses

$* * * p<.001, * * p<.01, * p<.05,^{\dagger} p<.10$

Sectoral controls and years included

Random effects maximum likelihood estimator

Private Indian firm: omitted benchmark ownership category

and independent firms that are significant (i.e., corresponding to Hypotheses 1 and 2). The figures present the marginal effects on profitability of changes in our risk measure (Fig. 1) and of changes in retained earnings (Fig. 2). These marginal effects are

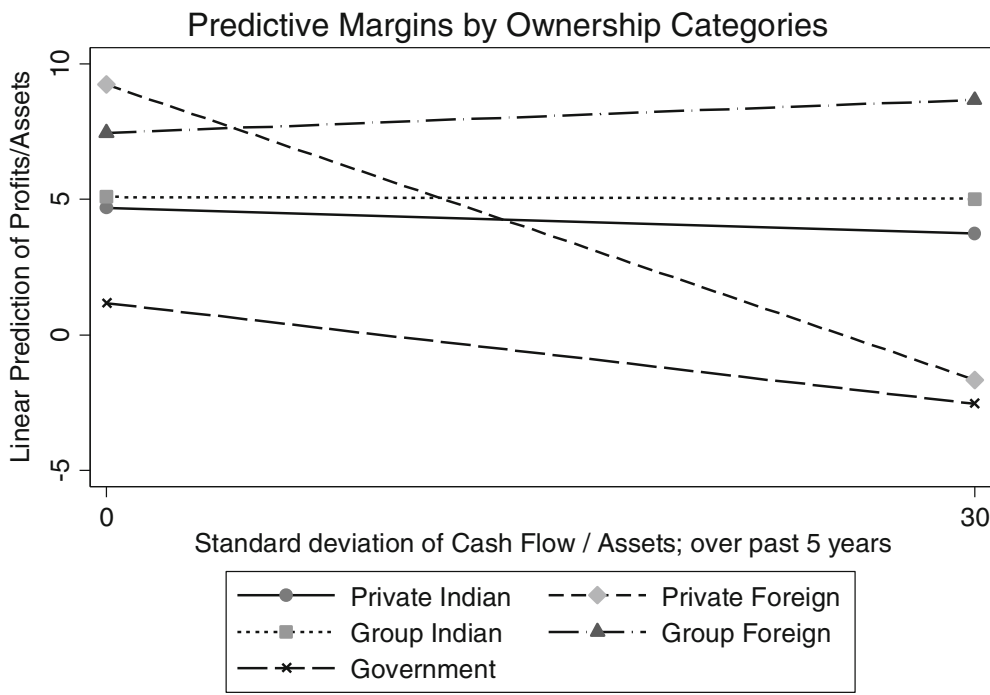

Fig. 1 The figure shows the association between profitability and risk-taking (proxied by past variability in profits). The risk-taking has (mean) negative impact on profitability of independent Indian companies, but not on group affiliated Indian companies. It is particularly bad for independent (not affiliated) Foreign companies 


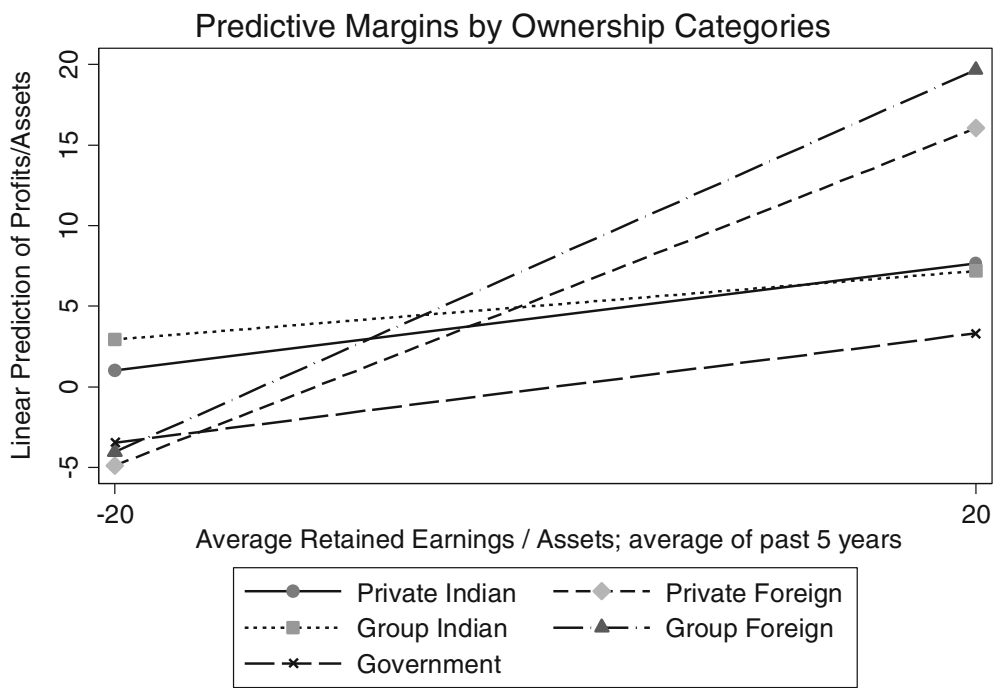

Fig. 2 The figure shows the association between profitability and proactiveness (proxied by past propensity to retain earnings). For both types of Indian companies the effect on profitability is positive, but less so for group affiliated companies

generated for all the five ownership categories separately, represented by five lines on the graphs correspondingly. The range of these EO components lie between one standard deviation below their respective mean values to one standard deviation above these mean values, and the values of all other explanatory variables are held at their average values. We have integrated the interpretation of these figures with the discussion of the regression estimates and of the implications for the hypotheses below.

\section{Discussion}

\section{Profitability, risk-taking, and group ownership}

We predicted that business group affiliated firms will be able to manage risks using internal capital markets, so that they would be more successful at translating risk-taking into profits than their independent counterparts. Within the regression framework, H1 implies that the sign on the interaction between cash flow volatility and the Indian group affiliation dummy variable will be positive and statistically significant in Columns 2 and 3 . The results indicate that there is support for H1. The coefficient of the interaction between cash flow volatility and the dummy for business group affiliation is positive at .07 and highly significant in Column 2; when all other ownership effects are added, it reduces to .03 in Column 3 though with lower significance (it is .04 in the fixed effects estimation, significant at the 5\% level).

The regression results permit us to calculate the corresponding estimates of the impact of the risk-taking component of EO on the profitability of independent Indian private firms and of group affiliated firms. Since the omitted ownership category in our regression Columns 2 and 3 is private independent Indian firms, the coefficient of the cash flow volatility variable itself measures the impact of risk-taking on the profitability of independent domestic firms. The estimates (in Columns 2 and 3) are -.07 and -.03 
correspondingly, both highly significant. By contrast, the overall impact of risk-taking on the profitability of group affiliated firms is around zero; the negative coefficient of cash flow volatility for both of these models is exactly offset by the positive coefficient of the interaction between cash flow volatility and the dummy variable for group affiliated firms. These effects correspond to the slopes of the lines presented at Fig. 1: the slope for the Indian business group affiliates is close to zero, yet it is negative for domestic independent firms. On the left hand side of Fig. 1, with no risk-taking, there is also no difference in predicted profitability levels between the business group affiliated and independent Indian firms. On the right hand side however, with considerable risktaking, the results diverge: the profitability of business groups affiliates remain at the same level, but decreases for independent Indian companies. ${ }^{14}$ We therefore find evidence for the mutual insurance effect identified in our theoretical framework; risktaking has a smaller negative impact on the performance of group affiliated firms, compared to the effect on the performance of private independent firms.

\section{Profitability, proactiveness, and ownership types}

We predicted in Hypothesis 2 that the positive impact of retained earnings on profitability will be weaker for business group affiliated firms than for private independent firms. This implies that the sign on the interaction between this and the group affiliation dummy variable would be negative and statistically significant in Columns 2 and 3 of Table 4. The coefficients of the interaction between retained earnings and the group affiliation dummy are negative-between -.06 and-.09 for the random effects Columns 2-3 (and -.06 for the fixed effects model) - and in all cases highly significant at the $1 \%$ o level, consistent with Hypothesis 2.

As before, the coefficient of the retained earnings variable itself gives us the impact of proactiveness on the profitability of private independent firms in Columns 2 and 3 while the interaction between retained earnings and the dummy for business group affiliation gives us the moderating effect of group affiliation on the relationship between proactivity and profitability. For example, in Column 2, this implies that the impact of proactiveness on firm performance is weaker for group affiliated firms $(.11=.20-.09)$ than for the private independent firms (.20). This corresponds to the steeper positive slope for independent domestic firms compared with domestic group affiliates depicted in Fig. 2. Exactly the same difference between the impact of proactiveness on profitability in group affiliated $(.11=.17-.06)$ and private independent firms $(.15)$ is also reflected by estimates presented in Column 3. ${ }^{15}$ As predicted, therefore, group affiliated firms are less able to translate the proactive strategy of retaining earnings (presumably for future investments) into profits than their private independent counterparts.

\footnotetext{
${ }^{14}$ These results are sharper for the fixed effects estimator; the impact of risk-taking on the profitability of domestic group affiliates is positive, as against nearly zero for independent private firms.

${ }^{15}$ In the fixed effect model corresponding to Column 2, both the effects and the difference were slightly attenuated, but nevertheless remained highly significant $(.04=.10-.06$, correspondingly).
} 


\section{Firm performance, knowledge acquisition, and group ownership}

In Hypothesis 3, we predicted that knowledge acquisition will have less of an impact on the profitability of group affiliated firms than private independent firms. Within the regression framework, the hypothesis implies that the sign on the interaction between knowledge acquisition and the Indian group affiliation dummy variable will be negative and statistically significant in Columns 2 and 3. Our results support the idea that knowledge acquisition as such has a positive impact on performance (the coefficient in Column 1 is highly significant at the $1 \%$ o level). However, the coefficients of the interaction between knowledge acquisition and the dummy variable for domestic group affiliated firms in Models 2 and 3 are statistically insignificant. In other words, while knowledge acquisition has a positive effect on performance of both private independent firms (.79, in Column 3 ) and business group affiliated firms, there is no statistically significant difference between the knowledge acquisition-performance relationship between these types of firms. Our findings therefore do not provide support for Hypothesis 3. Since the difference between the knowledge acquisition-performance relationship for business group affiliates and private independent firms is statistically insignificant, we do not provide a graphical analysis of this result.

\section{Profitability, EO strategies, and other ownership types}

Our results also offer interesting insights about the moderating effects of ownership type on the relationship between the dimensions of EO and profitability for firms with other ownership structures. The results in Column 1 of Table 4 suggest that both independent and group-affiliated foreign firms perform better than any category of domestic Indian firms, which is broadly consistent with the existing literature (Chibber \& Majumdar, 1999; Douma et al., 2006). At the same time, state-owned enterprises do not perform as well as private independent firms. This is consistent with both the general and Indiaspecific literature that compares performance of state-owned and private enterprises (Chibber \& Majumdar, 1998; Driffield, Mickiewicz, \& Temouri, 2013; Estrin, Kocenda, Hanousek, \& Svejnar, 2009; Goldeng, Grunfeld, \& Benito, 2008).

We now turn to the impact of the moderating impact of foreign and state ownership on the relationship between risk-taking and profitability. As illustrated by Fig. 1, our results suggest that risk-taking is associated with much bigger drop in the profits of independent foreign firms than for independent domestic firms. At the same time, the moderating impact is insignificant though positive for the handful of group affiliated foreign firms in our sample. This is consistent with the wider literature on liability of foreignness and institutional distance (Eden \& Miller, 2004; Xu \& Shenkar, 2002; Zaheer, 1995), one of whose implications is that foreign firms may find it difficult to devise and/or implement strategies that are optimal for the host country context. An interesting contribution we make however is that there is a clear contrast between independent and multinational-affiliated foreign firms - it is exactly the same contrast that we have identified between the independent and group affiliated Indian firms.

Risk-taking is also detrimental for the profitability of state-owned enterprises, although not nearly as much as for independent foreign firms. This could be on account of the well-understood multiplicity of strategic objectives of state-owned enterprises, whose management have continually to strike a balance between business and political 
objectives (Bai \& Xu, 2005; Driffield et al., 2013; Estrin et al., 2009; Zif, 1981). Other explanations include the moral hazard problems caused by soft budget constraints, the weak contractual incentives and managerial capacity, especially in managing projects associated with risk-taking behavior (Driffield et al., 2013; Kornai, Maskin, \& Roland, 2003; Shirley \& Xu, 1998).

Next, we turn to the impact of foreign and state ownership of firms on the relationship between proactiveness and firm performance. Our results suggest that for both government-held and foreign firms, proactiveness results in better firm performance relative to both independent private domestic and business group affiliated domestic firms; see Fig. 2. Our speculative interpretation of this result is as follows. Proactiveness for both types of firms may reflect their autonomy and managerial capacity more than their business strategy. The ability of a state-owned enterprise to retain a proportion of its profits for future investment, rather than return the profits to the government to help mitigate the latter's budget deficits or to facilitate its investment in projects that have political priority, can be interpreted as functional autonomy that can result in better internal governance and an increase in the workers' incentive to work in the interest of the firm (Aivazian, Ge, \& Qiu, 2005; Groves, Hong, McMillan, \& Naughton, 1994). In the same vein, a foreign firm's ability to retain a share of its profits, rather than to transfer it to the parent multinational enterprise, may reflect a desirable characteristic of a multinational enterprise's global network (Birkinshaw, Hood, \& Jonsson, 1998). In both cases, the firm's ability to be proactive may also reflect recognition of the managerial capacity by the owner.

For knowledge acquisition, there is little to add to the previous weak findings, except for a (marginally significant) premium for private foreign compared with private Indian firms.

\section{Other controls}

Finally, the coefficients in Columns 1-3 suggest that older firms are more profitable, which is consistent with the institutional void perspective; there is a premium to experience. ${ }^{16}$ There are no significant effects related to debtequity ratio and to the size of company as measured by tangible assets. The control variable for our measure of proactivity, representing positive profits in the past, is as expected positive and highly significant. The industry and time dummies are both jointly significant. ${ }^{17}$

\footnotetext{
${ }^{16}$ This result is even stronger in the fixed effects model.

${ }^{17}$ This implies that there was considerable variation in corporate profitability both between industries. Available evidence suggests that there was indeed significant variation in profitability across Indian industries, at least during the 1996-2007 period and that firm level profitability was indeed significantly correlated with sector-wide profitability (Mody, Nath, \& Walton, 2010). Our result is also consistent with data available from https://data.gov.in/which indicates that there was considerable variation in inter-industry and inter-year growth of the industrial sector during the 2005-2006 to 2010-2011 time period.
} 


\section{Conclusions}

Our research is motivated by the observation that fast growing firms from emerging economies have made rapid inroads into the global market place over the last two decades, and are challenging the hegemony of firms from the developed countries. The ability of these emerging market firms to sustain the competitive pressure on their developed economy counterparts is dependent on their ability to successfully adopt entrepreneurial strategies, and to translate these strategies into performance. We posit however that this ability is mitigated by the organizational structures these ventures are led to adopt by the institutional contexts in which they operate.

The emerging economies are characterized by weak institutions, and managers in these countries may respond to these weaknesses by adopting strategies that build on the comparative advantages of ownership structures of their businesses. In particular, membership of business groups may protect the affiliates against external risks but that this comes at the cost of some inefficiency in the allocation of financial resources and moral hazard among managers of individual member firms. Business group membership makes taking risks a more effective managerial strategy by providing mutual insurance and access to capital. On the other hand, internal redistribution acts as a disincentive on managers by breaking the link between profits and performance. We have separated the discussion of these two effects because they are not a simple trade-off. For some managers, the crucial opportunity may be risk-taking; for others, the capacity to pursue investment opportunities may prove decisive. We operationalize this heterogeneity in the way mutual insurance affects business group affiliated firm managers by using the EO construct that separately account for risk-taking and proactiveness attributes of firm management.

Our results highlight the presence of this trade-off in India, a fast growing emerging market that is the home of many of the companies that are now competing successfully on global markets. The results indicate that business group affiliation is beneficial for companies that want to take on risk; in contrast, risk-taking has a negative impact on firm profitability for private independent firms. However, these insurance benefits of business group membership may come at the cost of reducing returns to investment. The returns to proactive strategies have been found to be positive in India, as developed market economies (Miller, 1983). However, these returns increase at lower rate for business groups affiliates than for independent companies.

The net impact of these two opposing effects of business group membership (risk-taking and proactiveness) is difficult to predict, but the literature provides some indications about the overall outcome. It has been argued, for example, that risk-taking by firms is positively correlated with the quality of investor protection in a country (John, Litov, \& Yeung, 2008). At the same time, family ownership, which significantly overlaps with business group structures in emerging economies, promotes entrepreneurial risk-taking, but this effect is considerably weakened or even reversed if CEO-founders have long tenure (Zahra, 2005), which also characterises business groups in contexts such as India. Reluctance of business groups (and family firms) to engage in outward 
investment is also observed (Bhaumik, Driffield, \& Pal, 2010). In other words, risk-taking may not be the strongest aspect of entrepreneurial orientation of emerging economy firms, thereby reducing the importance of the insurance role played by business groups. Indeed, business group membership might be more of a hedge against unanticipated shocks or poor performance in general, than an insurance to supplement strategic risk-taking. By contrast, the ability of business group affiliated firms to make significant investments by tapping internal capital markets provides them with a significant advantage over competitors, and yet this advantage does not seem to yield much dividend for business group firms in terms of profitability.

We also found that that knowledge acquisition, itself a broader concept than the notion of innovation used in the traditional EO literature, significantly affects firm performance in emerging economies. We obtained significant estimates of the positive impact of knowledge acquisition in both independent private firms and business group affiliated firms, but there is no difference in the knowledge acquisition-performance relationship of these two types of firms. We can infer from this that the advantages of business groups with respect to the ability to share knowledge within business groups (Chang \& Hong, 2000) is more than offset by factors such as hierarchical governance structures (Filatotchev et al., 2007) and moral hazard. ${ }^{18}$ While the positive impact of knowledge acquisition on performance bodes well for Indian (and, by extension, emerging market) firms, the statistically non-significant difference in this relationship between independent private firms and business group affiliated firms, despite their internal market for knowledge, managerial capabilities, and so on, raises questions about their efficacy in the changing business environment in emerging market economies. There is a need for further research into this important question.

Taken together, the implication of our results is that business group affiliated firms are not able to develop an edge from the use of knowledge, in a sense of transforming it into better performance. At the same time, the insurance advantages of business group affiliations may be weak, and hence may be more than offset by inefficient use of within-group financial resources. An interpretation of these results is that, while the importance of the challenges posed by competition from emerging economy firms, many of which are affiliated to business groups, cannot be understated, our results suggest that these business groups continue to have some weaknesses that might provide their developed economy competitors a window of opportunity to sustain their traditional competitive edge. More importantly, for the purpose of our and future research, there is little to suggest that business group affiliation moderate the relationship between EO components and firm performance in a way that justifies their continued existence in the changing emerging market business environments.

\section{Limitations}

We follow Miller and Le Breton-Miller (2011) in utilizing accounting data to capture the three pillars of EO, but in an emerging market context. This enables us to use for our analysis data that are objective in nature, and are therefore not vulnerable to different types of bias that are often found in subjective responses to survey data

\footnotetext{
$\overline{18}$ These arguments apply even more strongly to state-owned firms.
} 
(Beegle, Himelin, \& Ravallion, 2009; Bertrand \& Mullainathan, 2001). However, this approach also prevents us from investigating empirically additional dimensions that could only be introduced by using surveys. In particular, our approach allows us to have ex post measures of the EO components rather than ex ante measures. For example, we can measure the outcome of risk-taking, namely, cash flow variability, but not the act of risk-taking itself. In such cases, refined survey instruments that supplement accounting data can be of help: using both at the same time is a promising idea for any follow up to our study. Furthermore, we did not discuss how internal rewards systems and other organizational improvements may mitigate some of the negative effects we identified and there is need for further research in this area.

Our results suggest that the link between knowledge acquisition and performance is weaker for business group affiliated firms. At the same time, these firms may enjoy the advantages associated with sharing knowledge (or more broadly: tangible and intangible resources) internally with other firms associated with the business group (Chang \& Hong, 2000). The impact of knowledge acquisition on performance will depend on the company's absorptive capacity (Tsai, 2001) as firms need to assimilate (analyze, process, interpret, and understand) the information obtained from external sources (Zahra \& George, 2002). This is an important dimension that we cannot observe in our data, yet the one that could explain the heterogeneity within business group affiliates. More data and more research are needed to explore this further.

We also focus only on India, which, while very large, may have specific features limiting the generalizability of our findings (see also: Chang et al., 2006). There are many common features of emerging economies, but also some important elements of heterogeneity. In particular, the pattern of corporate growth in India, which, as in much of Asia, is driven by both independent firms and business groups, is likely to differ from that of China, where stateowned companies or partly privatized companies play an important role (Cuervo-Cazzura \& Ramamurti 2014). It might nevertheless be possible to argue that the basic trade-off on which we focus, between the greater ability to take risk on account of de facto risk underwriting by an entity larger than the firm and the ability of the firm to use internal resources efficiently, remains applicable for China as well.

\section{Implications for managerial practice}

We have addressed questions about how performance is affected by EO in different types of companies. Managers typically take the core ownership features of their companies as given, and then shape the strategies their firms adopt. Thus, it is important to ask how the effectiveness of a fundamental strategic dimension, such as taking risks to innovate, or aggressive accumulation of resources and its investment, impacts on firm performance in emerging economies, and how the results differ conditional on both group affiliation and on the market environment within which the firm operates. Our results suggest that managers of business group affiliates should utilize the competitive advantage that the governance structure offers by engaging in entrepreneurial risktaking. The head offices of business groups should also explore how to 
ameliorate the weakening of incentives to managers who are proactive or innovative. In contrast, proactiveness based on retained earnings, investment, and knowledge acquisition is always at the core of successful EO of independent companies. It is for this group of companies that we found evidence that spending on knowledge acquisition results in better performance. This result should not be read as suggesting that innovativeness and quest for knowledge is not important in the context of emerging economies, but that absorption and utilization of knowledge within emerging market group-affiliated firms exhibit significant variation, and therefore could be an important issue to explore further.

Our study has made important contributions to the theory of EO and business performance in emerging economies, by expanding our understanding of the specific dimensions upon which EO may be enhanced and where it may be inhibited. Specifically, we show that risk-taking may actually undermine rather than improve business performance for some types of firms in emerging economies. Similarly, it is usually argued that managers who follow intensive innovation based strategies in developed economies will enhance the performance of their companies. However, in emerging economies, firms can make significant market gains while still not operating as innovation leaders, as exemplified by the current case of Samsung competing successfully against Apple. Hence, bricolage-combining existing knowledge to match specific needs and conditions - may supplement innovation as the key driver of business performance in these business contexts. Relying more heavily on proactiveness, the third element of EO, may more than substitute for the weaker impact of innovativeness in emerging economies.

When considering corporate strategies in emerging economy firms, one must also take into account the greater variety of ownership arrangements compared with developed economies, most significantly the widespread prevalence of business groups. We show how the impact of the three aspects of EO may be moderated in firms which are business group affiliates, in comparison with the independent private companies that make up the bulk of competitors in developed economies. In so doing, we are better able to understand the potential longer-term performance implications of the business group corporate form for entrepreneurial strategies. Thus we find that business group affiliation provides benefits to emerging economy's firms that choose to take risks, relative to those that are unaffiliated, but simultaneously the returns to proactive strategies are weakened. Moreover, knowledge acquisition, itself a wider concept than innovation, does not significantly affect performance in emerging economy business group affiliated firms. Managers of business group affiliated companies from emerging economies should not concentrate on increasing spending on knowledge acquisition, but on learning how to make the process more effective, enhancing the absorptive capacity of their companies.

Acknowledgments The authors would like to thank Mike Carney, Nigel Driffield, Eric Gedajlovic, Paula Jarzabkowski, Costas Markides, Klaus Meyer, Daniel Shapiro, and two anonymous referees for useful suggestions and comments. Any remaining errors are our own. This paper was conceived 
and written while Saul Estrin was visiting the Strategy and Entrepreneurship Department at London Business School, and he gratefully acknowledges the support and intellectual stimulation. Sumon Bhaumik acknowledges the support of British Academy small grant (No. SG-54061) for acquisition of the Prowess data base. The order of authors' names is alphabetical, and their contribution is equal.

Open Access This article is distributed under the terms of the Creative Commons Attribution 4.0 International License (http://creativecommons.org/licenses/by/4.0/), which permits unrestricted use, distribution, and reproduction in any medium, provided you give appropriate credit to the original author(s) and the source, provide a link to the Creative Commons license, and indicate if changes were made.

\section{References}

Acemoglu, D., Aghion, P., \& Zilibotti, F. 2006. Growth, development and appropriate versus inappropriate institutions. Mimeo, Downloadable from http://www.ebrd.com/russian/downloads/ research/economics/japan/jrp1.pdf.

Aivazian, V. A., Ge, Y., \& Qiu, J. 2005. Can corporatization improve the performance of state-owned enterprises even without privatization?. Journal of Corporate Finance, 11(5): 791-808.

Aoki, M. 1984. Risk sharing in the corporate group. In M. Aoki (Ed.). The economic analysis of the Japanese firm. New York: North-Holland.

Aoki, M. 1988. Information, incentives and bargaining in the Japanese economy. Cambridge: Cambridge University Press.

Bai, C.-N., \& Xu, L. C. 2005. Incentives for CEOs with multitasks: Evidence from Chinese state-owned enterprises. Journal of Comparative Economics, 33(3): 517-539.

Baumol, W. J. 2010. The microtheory of innovative entrepreneurship. Princeton: Princeton University Press.

Bebchuk, L. A., Kraakman, R., \& Triantis, G. 2000. Stock pyramids, cross-ownership and dual-class equity: The mechanisms and agency costs of separating control from cash-flow rights. In R. Morck (Ed.). Concentrated corporate ownership: 445-460. Chicago: University of Chicago Press.

Beegle, K., Himelin, K., \& Ravallion, M. 2009. Frame-of-reference bias in subjective welfare regressions. Policy Research working paper no. 4904, The World Bank, Washington, DC.

Begley, T., \& Boyd, D. 1987. Psychological characteristics associated with performance in entrepreneurial firms and small businesses. Journal of Business Venturing, 2(1): 79-93.

Belenzon, S., \& Berkovitz, T. 2010. Innovation in business groups. Management Science, 56(3): 519-535.

Bertrand, M., Mehta, P., \& Mullainathan, S. 2002. Ferreting out tunnelling: An application to Indian business groups. Quarterly Journal of Economics, 117: 121-148.

Bertrand, M., \& Mullainathan, S. 2001. Do people mean what they say? Implications for subjective survey data. American Economic Review: Papers and Proceedings, 91(2): 67-72.

Bhaumik, S. K., \& Dimova, R. 2004. How important is ownership in a market with a level playing field: The Indian banking sector revisited. Journal of Comparative Economics, 32(1): 165-180.

Bhaumik, S. K., \& Dimova, R. 2014. How family firms differ: Structure, strategy, governance and performance. London: Palgrave Macmillan.

Bhaumik, S. K., Driffield, N., \& Pal, S. 2010. Does ownership structure of emerging-market firms affect their outward FDI? The case of Indian automotive and pharmaceutical sectors. Journal of International Business Studies, 41: 437-450.

Bhaumik, S. K., Gangopadhyay, S., \& Krishnan, S. 2009. Reforms and entry: Some evidence from the Indian manufacturing sector. Review of Development Economics, 13: 658-672.

Bhaumik, S. K., \& Selarka, E. 2012. Does ownership concentration improve M\&A outcomes in emerging markets? Evidence from India. Journal of Corporate Finance, 18: 717-726.

Bhaumik, S. K., \& Zhou, Y. 2014. Do business groups help or hinder technological progress in emerging markets? Evidence from India. Discussion paper no. 7885, Institute for the Study of Labor, Bonn.

Birkinshaw, J., Hood, N., \& Jonsson, S. 1998. Building firm-specific advantages in multinational corporations: The ole of subsidiary initiative. Strategic Management Journal, 19: 221-241.

Bruton, G. D., Ahlstrom, D., \& Obloj, K. 2007. Entrepreneurship in emerging economies: Where are we today and where should research go in the future. Entrepreneurship: Theory and Practice, 32: 1-14.

Carney, M. 2008. The many futures of Asian business groups. Asia Pacific Journal of Management, 25(4): 595-613. 
Carney, M., Estrin, S., Shapiro, D., \& van Essen, M. 2015. Cross-national and temporal differences in business group prevalence: Do they matter?. Mimeo, London School of Economics.

Carney, M., Gedajlovic, E., Huegens, P. P. M. A. R., van Essen, M., \& van Oosterhout, J. 2011. Business group affiliation, performance, context, and strategy: A meta-analysis. Academy of Management Journal, 54(3): 437-460.

Chacar, A., \& Vissa, B. 2005. Are emerging economies less efficient? Performance persistence and the impact of business group affiliation. Strategic Management Journal, 26(10): 933-946.

Chang, S., Chung, C., \& Mahmood, I. 2006. When and how does business group affiliation promote firm innovation? A tale of two emerging economies. Organization Science, 17(5): 637-656.

Chang, S. J., \& Hong, J. 2000. Economic performance of group-affiliated companies in Korea: Intragroup resource sharing and internal business transactions. Organization Science, 43: 429-448.

Chibber, P. K., \& Majumdar, S. K. 1998. State as investor and state as owner: Consequences for firm performance in India. Economic Development and Cultural Change, 46(3): 561-580.

Chibber, P. K., \& Majumdar, S. K. 1999. Foreign ownership and profitability: Property rights, control, and the performance of firms in the Indian industry. Journal of Law and Economics, 42(1): 209-238.

Choi, S. B., Lee, S. H., \& Williams, C. 2011. Ownership and firm innovation in a transition economy: Evidence from China. Research Policy, 40: 441-452.

Cohen, M., \& Levinthal, D. A. 1990. Absorptive capacity: A new perspective on learning and innovation. Administrative Science Quarterly, 35(1): 128-152.

Covin, J. G., \& Slevin, D. P. 1989. Strategic management of small firms in hostile and benign environments. Strategic Management Journal, 10: 75-87.

Covin, J. G., \& Slevin, D. P. 1991. A conceptual model of entrepreneurship as firm behaviour. Entrepreneurship: Theory and Practice, 16(1): 7-25.

Cuervo-Cazzura, A., \& Dau, L. A. 2009. Premarket reforms and firm profitability in developing countries. Academy of Management Journal, 52: 1348-1368.

Cuervo-Cazzura, A., \& Ramamurti, R. 2014. Understanding multinationals from emerging markets. Cambridge: Cambridge University Press.

Dekle, R., \& Pundit, M. 2016. The recent convergence of financial development in Asia. Emerging Markets Finance and Trade, 52: 1106-1120.

Douma, S., George, R., \& Kabir, R. 2006. Foreign and domestic ownership, business groups, and firm performance: Evidence from a large emerging market. Strategic Management Journal, 27(7): 637-657.

Driffield, N. L., Mickiewicz, T., \& Temouri, Y. 2013. Institutional reforms, productivity and profitability: From rents to competition?. Journal of Comparative Economics, 41(2): 583-600.

Eden, L., \& Miller, S. R. 2004. Distance matters: Liability of foreignness, institutional distance and ownership strategy. In M. A. Hitt \& J. L. C. Cheng (Eds.). Theories of the multinational enterprise: Diversity, complexity and relevance, Vol. 16: 187-221. Emerald: Bingley.

Estrin, S., Kocenda, E., Hanousek, J., \& Svejnar, J. 2009. The effects of privatization and ownership in transition economies. Journal of Economic Literature, 47(3): 699-728.

Estrin, S., Meyer, K., \& Pelletier, A. 2016. Emerging economy MNEs: How does home country maturity matter?. Mimeo, London School of Economics.

Estrin, S., Poukliakova, S., \& Shapiro, D. 2008. The performance effects of business groups in Russia. Journal of Management Studies, 46(2): 393-420.

Fama, E. F. 1968. Risk, return and equilibrium: Some clarifying comments. Journal of Finance, 23: 29-40.

Filatotchev, I., Isachenkova, N., \& Mickiewicz, T. 2007. Corporate governance, managers' independence, exporting, and performance of firms in transition economies. Emerging Markets Finance and Trade, 43(5): $65-80$.

Filatotchev, I., Wright, M., Uhlenbruck, K., Tihanyi, L., \& Hoskisson, R. 2003. Governance, organizational capabilities, and restructuring in transition economies. Journal of World Business, 38: 331-347.

Fogel, K. 2006. Oligarchic family control, social economic outcomes, and the quality of government. Journal of International Business Studies, 37: 603-622.

Frieman, E., Johnson, S., \& Mitton, T. 2003. Propping and tunnelling. Journal of Comparative Economics, 31: $732-750$.

Gedajlovic, E., \& Shapiro, D. 1998. Management and ownership effects: Evidence from five countries. Strategic Management Journal, 19(6): 533-553.

Gedalovic, E., \& Shapiro, D. M. 2002. Ownership structure and firm profitability in Japan. Academy of Management Journal, 45(3): 565-575.

Ghatak, M., \& Kali, R. 2001. Financially interlinked business groups. Journal of Economics and Management Strategy, 10: 591-619. 
Ghemawat, P., \& Khanna, T. 1998. The nature of diversified business groups: A research design and two case studies. Journal of Industrial Economics, 46: 35-61.

Goldeng, E., Grunfeld, L. A., \& Benito, G. R. G. 2008. The performance differential between private and state owned enterprises: The role of ownership, management and market structure. Journal of Management Studies, 45(7): 1244-1273.

Gopalan, R., Nanda, V., \& Seru, A. 2007. Affiliated firms and financial support: Evidence from Indian business groups. Journal of Financial Economics, 86: 759-795.

Gopinath, S. 2010. Over-the-counter derivative markets in India: Issues and perspectives. Financial Stability Review, Banque de France, 14: 61-69.

Groves, T., Hong, Y., McMillan, J., \& Naughton, B. 1994. Autonomy and incentives in Chinese state enterprises. Quarterly Journal of Economics, 109(1): 183-209.

Hart, S. L. 1992. An integrative framework for strategy-making processes. Academy of Management Review, 17: $327-351$.

Hoskisson, R., Eden, L., Lau, M., \& Wright, M. 2000. Strategy in emerging economies. Academy of Management Journal, 43(3): 249-267.

Jensen, M. C. 1986. Agency costs of free cash flow, corporate finance, and takeovers. American Economic Review, 76(2): 323-329.

John, K., Litov, L., \& Yeung, B. 2008. Corporate governance and risk-taking. Journal of Finance, 63(4): $1679-1728$.

Kaplan, S. N., \& Zingales, L. 1997. Do investment-cash flow sensitivities provide useful measures of financing constraints?. Quarterly Journal of Economics, 112: 169-215.

Kedi, B. L., Mukherjee, D., \& Lahiri, S. 2006. Indian business groups: Evolution and transformation. Asia Pacific Journal of Management, 23(4): 559-577.

Keister, L. A. 1998. Engineering growth: Business group structure and firm performance in China's transition economy. American Journal of Sociology, 104: 404-440.

Khanna, T. 2000. Business groups and social welfare in emerging markets: Existing evidence and unanswered questions. European Economic Review, 44: 748-761.

Khanna, T. 2011. Billions of entrepreneurs. How China and India are reshaping their futures and ours. Boston: Harvard Business Review Press.

Khanna, T., \& Palepu, K. G. 1997. Why focused strategies may be wrong for emerging markets. Harvard Business Review, 75: 3-10.

Khanna, T., \& Palepu, K. G. 2000. The future of business groups in emerging markets: Long-run evidence from Chile. Academy of Management Journal, 43: 268-286.

Khanna, T., \& Rivkin, J. W. 2001. Estimating the performance effects of business groups in emerging markets. Strategic Management Journal, 22: 45-74.

Khanna, T., \& Yafeh, Y. 2005. Business groups and risk sharing around the world*. Journal of Business, 78(1): 301-340.

Khanna, T., \& Yafeh, Y. 2007. Business groups in emerging markets: Paragons or parasites?. Journal of Economic Literature, 45: 331-372.

Kirzner, I. M. 1973. Competition and entrepreneurship. Chicago: University of Chicago Press.

Kornai, J., Maskin, E., \& Roland, G. 2003. The concept of soft budget constraint. Journal of Economic Literature, 61: 1095-1136.

KPMG. 2013. Insurance industry_Road ahead (in collaboration with Bengal Chamber). https://www.kpmg. com/IN/en/IssuesAndInsights/ArticlesPublications/Documents/Insurance_industry_Road_ahead_FINAL. pdf, accessed Apr. 13, 2016.

Krishnan, K. P. 2011. Financial development in emerging markets: The Indian experience. Working paper no. 276, ADB Institute, Downloadable from http://www.adb.org/sites/default/files/publication/156131/adbiwp276.pdf.

Li, H., \& Atuahene-Gima, K. 2001. Product innovation strategy and the performance of new technology ventures in China. Academy of Management Journal, 44(6): 1123-1134.

Lumpkin, G. T., \& Dess, G. G. 1996. Clarifying the entrepreneurial orientation construct and linking it to performance. Academy of Management Review, 21(1): 135-172.

Meeks, G. 1977. Disappointing marriage: A study of the gains from merger. Cambridge: Cambridge University Press.

Miller, D. 1983. The correlates of entrepreneurship in three types of firms. Management Science, 27: 770-792.

Miller, D., \& Bromiley, P. 1990. Strategic risk and corporate performance: An analysis of alternative risk measures. Academy of Management Journal, 33: 756-779.

Miller, D., \& Friesen, P. 1982. Innovation in conservative and entrepreneurial firms: Two models of strategic momentum. Strategic Management Journal, 3: 1-25. 
Miller, D., \& Le Breton-Miller, I. 2011. Governance, social identity, and entrepreneurial orientation in closely held public companies. Entrepreneurship: Theory and Practice, 35: 1051-1076.

Minniti, M., \& Lévesque, M. 2010. Entrepreneurial types and economic growth. Journal of Business Venturing, 25: 305-314.

Mody, A., Nath, A., \& Walton, M. 2010. Sources of corporate profits in India-Business dynamism or advantages of entrenchment?. CID working paper no. 212, Centre for International Development, Harvard University.

Morck, R., Wolfenzon, D., \& Yeung, B. 2005. Corporate governance, economic entrenchment and growth. Journal of Economic Literature, 43: 657-722.

Morck, R., \& Yeung, B. 2003. Agency problems in large family business groups. Entrepreneurship: Theory and Practice, 27(4): 367-382.

Morck, R., \& Yeung 2004. Family control and the rent seeking society. Entrepreneurship: Theory and Practice, 28: 391-409.

Mudambi, R., \& Navarra, P. 2004. Is knowledge power? Knowledge flows, subsidiary power and rent-seeking within MNCs. Journal of International Business Studies, 35: 385-406.

O’Neil, J. 2011. The growth map. London: Portfolio Penguin.

Palepu, K., \& Khanna, T. 1999. The right way to restructure conglomerates in emerging markets. Harvard Business Review, 77(4): 125-134.

Peng, M. W. 2006. Global strategy. Cincinnati: Thomson South-Western.

Peng, M. W., \& Delios, A. 2006. What determines the scope of the firm over time and around the world? An Asia Pacific perspective. Asia Pacific Journal of Management, 23(4): 385-406.

Peng, M. W., Lee, S., \& Wang, D. 2005. How network strategies and institutional transitions evolve in Asia. Asia Pacific Journal of Management, 22(4): 321-336.

Rajagopalan, N., Rasheed, A., \& Datta, D. 1993. Strategic decision processes: Critical review for future directions. Journal of Management, 19: 349-384.

Riyanto, Y. E., \& Toolsema, L. A. 2008. Tunnelling and propping: A justification for pyramidal ownership. Journal of Banking \& Finance, 32: 253-272.

Rodrik, D., \& Subramanian, A. 2004. From "Hindu growth" to productivity surge: The mystery of Indian growth transition, Working paper no. 10376, National Bureau of Economic Research, Cambridge.

Sarkar, N., \& Mukhopadhyay, D. 2005. Testing predictability and nonlinear dependence in the Indian stock market. Emerging Markets Finance and Trade, 51: 7-44.

Shin, H. H., \& Park, Y. S. 1999. Financing constraints and internal capital markets: Evidence from Korean 'chaebols'. Journal of Corporate Finance, 5(2): 169-191.

Shin, H. H., \& Stulz, R. M. 1998. Are internal capital markets efficient?. Quarterly Journal of Economics, 113(2): 531-552.

Shirley, M. M., \& Xu, L. C. 1998. Information, incentives, and commitment: An empirical analysis of contracts between government and state enterprises. Journal of Law, Economics, and Organization, 14(2): 358-378.

Steier, L. P. 2009. Familial capitalism in global institutional contexts: Implications for corporate governance and entrepreneurship in East Asia. Asia Pacific Journal of Management, 26(3): 513-535.

Stein, J. C., Usher, S., LaGattuta, D., \& Youngen, J. 2001. A comparables approach to measuring cashflow-at-risk for nonfinancial firms. Journal of Applied Corporate Finance, 13: 8-17.

Thomsen, S., \& Pedersen, T. 2000. Ownership structure and economic performance in the largest European companies. Strategic Management Journal, 21(6): 689.

Tsai, W. 2001. Knowledge transfer in intraorganizational networks: Effects of network position and absorptive capacity on business unit innovation and performance. Academy of Management Journal, 44: 996-1004.

Wales, W. J., Monsen, E., \& McKelvie, A. 2011. The organizational pervasiveness of entrepreneurial orientation. Entrepreneurship: Theory and Practice, 35(5): 895-923.

Weidenbaum, M. 1996. The Chinese family business enterprise. California Management Review, 38: 141156.

Xu, D., \& Shenkar, O. 2002. Note: Institutional distance and the multinational enterprise. Academy of Management Review, 27(4): 608-618.

Zaheer, S. 1995. Overcoming the liability of foreignness. Academy of Management Journal, 38(2): 341-363.

Zahra, S. A. 2005. Entrepreneurial risk-taking and family firms. Family Business Review, 18(1): 23-40.

Zahra, S. A., \& George, G. 2002. Absorptive capacity: A review, reconceptualization, and extension. Academy of Management Review, 27: 185-200.

Zif, J. 1981. Managerial strategic behaviour in state-owned enterprises-Business and political orientations. Management Science, 27(11): 1326-1339. 
Sumon Kumar Bhaumik (PhD, University of Southern California) at present has a Chair in Finance at the University of Sheffield, and is also a Research Fellow at IZA - Institute for the Study of Labor, Bonn. His research interests include impact of ownership and corporate governance structures on performance, behavior, and strategy of financial and non-financial firms. His research also extends to issues related to financial intermediation and internationalization of emerging market firms. He has published in journals such as the Strategic Management Journal, Journal of International Business Studies, Journal of Corporate Finance, Journal of Banking and Finance, and Journal of Development Economics.

Saul Estrin (DPhil, University of Sussex) is a professor of management at the London School of Economics. He was formerly Adecco Professor of Business and Society at London Business School where he was the Research Director of the Centre for New and Emerging Markets and Director of the CIS Middle Europe Centre. Saul's main areas of research are emerging markets, with a particular focus on entrepreneurship and international business issues. His research interests have included transition economies, notably Central Europe and China. He has been a visiting Professor at Stanford University, Michigan Business School, Cornell University, and the European University Institute. He is a Fellow of the Centre for Economic Policy Research and the Institute for the Study of Labor in Bonn (IZA).

Tomasz Mickiewicz ( $\mathrm{PhD}$, Catholic University of Lublin) is a 50th Anniversary Professor of Economics at Aston Business School, Aston University, Birmingham, and honorary research fellow at University College London. His research is on commercial and social entrepreneurship, in particular on how institutional environment affects entrepreneurial aspirations. He is a fellow at the ESRC Enterprise Research Centre, an associate editor of Regional Studies, member of the editorial review board of Entrepreneurship Theory and Practice, and a former president of the European Association for Comparative Economic Studies. His current publications (2012-2016) include papers in the Journal of Business Venturing, Entrepreneurship Theory and Practice, International Small Business Journal, Small Business Economics, Journal of Comparative Economics, Corporate Governance International Review, and others. 